\title{
Rituximab and Hyaluronidase Human Regimen
}

National Cancer Institute

\section{Source}

National Cancer Institute. Rituximab and Hyaluronidase Human Regimen. NCI

Thesaurus. Code C160114.

A chemo/immunotherapy regimen consisting of rituximab and human hyaluronidase that may be used in the treatment of chronic lymphocytic leukemia (CLL); and small lymphocytic, follicular, diffuse large B-cell and primary cutaneous B-cell lymphomas. 